\title{
Indian IT MNEs and the Transfer of HRM Practices in their Subsidiaries in Developed Countries
}

\author{
Parth Patel* \\ Lecturer in International HRM \& Business \\ Discipline of Management and Human Resources \\ Australian Institute of Business \\ 27 Currie Street, Adelaide, South Australia 5000, Australia \\ Telephone: +61 (08) 70891315, Email: parth.patel@aib.edu.au \\ Ramudu Bhanugopan \\ Associate Professor of Human Resource Management \\ School of Management and Marketing \\ Faculty of Business, Justice and Behavioural Sciences \\ Charles Sturt University \\ Boorooma Street, Wagga Wagga, New South Wales 2678, Australia \\ Telephone: +61 (02)69332696, Email: bramudu@csu.edu.au
}

*=corresponding author 


\title{
Indian IT MNEs and the Transfer of HRM Practices in their Subsidiaries in Developed Countries
}

\begin{abstract}
There is a growing literature on emerging market multinational enterprises and the extent to which they diffuse or transfer their HRM practices in foreign subsidiaries. Much of the research, however, has looked at understanding the HRM practices of MNEs from developed countries operating in developing countries. There is limited research and discussion regarding MNEs from emerging economies and the way they manage their HR practices in their subsidiaries in developed countries. This study investigates the transfer of HRM practices in Indian IT MNEs with subsidiaries in Australia and draws on data collected through multiple case studies with interviews from top directors and managers in their Australian subsidiaries. The findings reveal that emerging MNEs do not behave very differently from their Western counterparts and instead of relying on a polycentric HR model; they adopt a mix of ethnocentric and polycentric approach to international HRM that merges home-country policies with locally responsive practices. However, the majority of the HRM practices in the Australian subsidiaries originate from the parent-country operations in India with some modification to suit and fit into the Australian subsidiary context. Implications for theory and practice have been discussed.
\end{abstract}

Keywords: MNEs, Emerging Economies, HRM Practices, India, Australia 


\section{Indian IT MNEs and the Transfer of HRM Practices in their Subsidiaries in Developed Countries}

\section{Introduction}

Multinational enterprises (MNEs) operating overseas often seek suitable strategies to their international HRM (IHRM) approaches in their foreign subsidiaries (Fan, Zhang and Zhu, 2013). Within this literature, one significant line of enquiry relates to the ability of these MNEs to achieve international integration of its policies and practices (Kim et al., 2003). In particular, the issue of global standardisation versus local adaptation of subsidiary-HRM practices has been a central issue in the literature on human resource management (HRM) in multinational enterprises (Festing et al., 2012, Pudelko and Harzing, 2007). The majority of these debates, however, have looked at investigating MNEs from developed countries with subsidiaries in developing countries (Chen, Lawler and Bae, 2005; Ferner, 2009; Fey and Bjorkman, 2001; Glover and Wilkinson, 2007; Lovett, Perez-Nordtvedt and Rasheed, 2009). Not much research has examined the HRM practices of MNEs from emerging economies (EMNEs) operating their subsidiaries in developed countries (Chang, Mellahi and Wilkinson, 2009; Gomes et al., 2014; Horwitz and Budhwar, 2015; Ying Chang, Wilkinson and Mellahi, 2007; Fan, Zhang and Zhu, 2013; Thite, Wilkinson and Shah, 2012). This paper adds to this underdeveloped but growing research agenda.

There are two important reasons for conducting this research. First, there is a growing recognition in the international HRM literature that national differences in HR practices remain 
persistently distinct (Edwards et al., 2016), and that MNEs in more cases than less have to fit in with the local realities in host countries. Accordingly, unlike MNEs from developed countries that engage in the forward diffusion of their home-country HRM practices, EMNEs employ the knowledge gained by operating in developed countries to transfer their "best" practices (Zhang et al., 2008). As a result, they are more likely to adopt a polycentric or an "adaptive" approach to managing their subsidiaries in developed countries (Thite, Wilkinson and Shah, 2012; Thite, 2012; 2015). Second, when competing in developed markets, EMNEs face double hurdles of the liability of country of origin and foreignness (Horwitz and Budhwar, 2015) which occurs due to the perceived weaknesses in MNE home-country economy and institutions (Chand, Mellahi and Wilkinson, 2009) as well as due to gaps in understanding caused by cultural variations (Calhoun, 2002; Gaur, Kumar and Sarathy, 2011; Yildiz and Fey, 2012). This forces EMNEs to emulate host-country HR policies and practices as they originate from a country with less comparative advantage (including possessing significant cultural differences) (Almond, 2011; Edwards and Ferner, 2004; Ying Chang, Wilkinson and Mellahi, 2007). This raises questions regarding the transferability of country-of-origin HR models and the extent to which EMNEs can apply them to their foreign subsidiaries (Khavul, Benson and Datta, 2010; Zhu, Thompson and De Cieri, 2008). With such variations amid the "Western" approach to HRM that would be taken by MNEs from emerging economies (Oyelere, 2014), it is worth investigating whether and how EMNEs manage their subsidiaries in developed countries with regards to their international HR.

In this article, we explore the HRM strategies of EMNEs and how they operate in practice in their subsidiaries in developed countries. For this paper, we have focused on a sample of Indian information technology (IT) MNEs with subsidiaries in Australia. McDonnell, Stanton and 
Burgess (2011) have called for more empirical research on emerging MNE behaviour in advanced economies, like Australia, as it has remained a neglected area. So we believe that Indian IT MNEs in the Australian context may provide a unique and interesting backdrop for this study as they have developed a strong global reputation for pioneering the global services delivery model that leverages the strengths of their global workforce (Thite, Budhwar and Wilkinson, 2014). Budhwar and Varma (2011) note that the HR policies and practices of Indian IT MNEs are matched with those that are best in the world. This indicates that Indian IT MNEs may not require the adoption of host-country HRM practices found in developed countries as they enjoy international competitive advantages through access to cheap skilled labour. However, given that extant literature points towards EMNEs adopting a polycentric/adaptive approach to global HR practices (Thite et al., 2012; Thite, 2015); we question whether this proposition is compatible with Indian IT MNEs in general, their business model and the way they manage HRM in their subsidiaries in developed markets. Currently, not much is known about the role that international HRM plays in this industry (Thite, Budhwar and Wilkinson, 2014) and hardly any attention has been paid to understanding IHRM in the Indian IT sector (Mathew and Jain, 2008). As such, this article draws on the stream of literature on HRM practices in MNEs from emerging economies to explore and investigate the transfer of HR practices by Indian IT MNEs in their subsidiaries in Australia by answering the following questions:

1. How do Indian IT MNEs transfer their HRM practices in their subsidiaries in developed countries? 
2. How do the liabilities of country of origin and foreignness in Indian IT MNEs influence the transfer of their HR practices in the host-country?

This article is based on the conceptual framework of standardisation towards headquarters (HQ), standardisation towards global "best" practices and localisation of HRM practices - also referred to as the "Golden Triangle" for MNEs (Pudelko and Harzing, 2008). This framework has been selected as it is central to International HRM and is connected to the "global versus local" dilemma faced by all MNEs. It is also the most current and up-to-date model that encompasses all the integration-localisation choices faced by MNEs and therefore extends the debate on the transfer, and particularly the standardisation versus localisation of HR practices. Interestingly, the literature indicates that despite plenty of research there remains a considerable variety in the HR policies and practices adopted by MNEs (Wilkinson, Wood and Demirbag, 2014). This holds particularly true for EMNEs where a considerable degree of variance has been found with regards to the convergence or divergence of HRM practices which limits our ability to draw valid and reliable conclusions (Thite, 2015). For example, Indian IT MNEs have been found to use an "adaptive" approach to managing their subsidiaries in developed markets and a localised approach in developing countries (Thite, Wilkinson and Shah, 2012). Accordingly, more studies are required in order to advance our understanding of EMNEs and how they deal with the differentiation vs. localisation of their international HR in their foreign subsidiaries.

The structure of this paper is as follows. First, this article reviews the literature that describes the current international HRM practices adopted by Indian IT firms. Second, the article presents the theoretical framework adopted for this study. Third, the article describes the research methods 
that are used in investigating the International HR practices of Indian MNEs in their Australian subsidiaries. Fourth, the findings are presented, and analysed; fifth, the paper discusses the theoretical and practical implications of this research together with the limitations and provides avenues for future research; and finally, the conclusion is presented.

\section{HRM Practices in Indian IT MNEs}

The Indian IT sector gained prominence in the 1990s (Mathew and Jain, 2008) and since then there have been major developments in the trends of HRM in this sector with respect to both, pre and post liberalisation eras. However, given the importance of India in the global economy (Budhwar and Varma, 2010; Kumar, 2013; Nilekani, 2009) scholarly literature on HRM in the Indian IT context is surprisingly scarce which has made it difficult to gain concrete understanding into the HR issues in this industry (Budhwar and Bhatnagar, 2009; Pio, 2007) and especially its multinational enterprises. Traditionally, HRM and management, generally, in Indian organisations have been found to be distinctive from the practices adopted in the Western world (Cappelli et al., 2010; Chatterjee, 2007; Sparrow and Budhwar, 1997) thereby suggesting that majority of those practices are culture specific (Budhwar and Khatri, 2001). However, the extant literature indicates that this may not be particularly true when it comes to HR in Indian IT firms and its MNEs where traditional norms and HR practices are not strictly followed (Budhwar et al., 2009; Khandekar and Sharma, 2005; 2006). This may be due to the rapid developments in the Indian economy and its infrastructure (Budhwar et al., 2006) including the arrival of a large number of foreign MNEs to India resulting in the crossvergence of various HRM practices and work cultures (Saini and Budhwar, 2013). Furthermore, knowledge-based industries and in 
particular, the Indian IT industry is also growing rapidly which is leading to the development of sector-specific HR patterns (Budhwar, 2008). For instance, formal testing of job applicants, job evaluation, training needs analysis, and performance-based pay are some of the examples of highly structured systems found in the Indian IT sector (Budhwar, Luthar and Bhatnagar, 2006) including practices that are also used by its MNEs. Accordingly, HR in Indian IT firms is known to be more distinctive and different from the more traditional parts of the Indian economy, with more emphasis on formal, structured and rationalised HRM systems (Budhwar et al., 2006). To distinguish how Indian IT MNEs transfer their HRM practices to their subsidiaries in developed countries, we use the extant literature to identify the international HRM practices used by Indian IT firms (see Table 1) and compare it with our empirical findings to show what HR practices were found in their subsidiaries in Australia. The literature below describes those HR practices that are typically used by Indian IT firms to manage their subsidiaries in foreign countries:

\section{Recruitment \& Selection}

Indian firms and MNEs in the IT sector are known to follow a highlight formalised and structured recruitment system which relies on sending professional and managerial staff from their parent headquarters (HQ) to their foreign subsidiaries (Budhwar et al., 2006; Mathew and Jain, 2008). Due to the high attrition rate among employees in Indian IT firms (Agrawal and Thite, 2003) these MNEs often rely on internal transfers and job rotation to fill vacancies in their overseas subsidiaries (Ghosh, 2007) as this allows them to maintain lower employee turnover rates. However, when unable to fill through internal sources, Indian IT firms also rely on external sources using online recruitment websites, advertisements, referrals, campus recruitment and 
executive search agencies to fill technical and managerial positions and hire key staff (Sethi, 2005).

\section{Training \& Development}

Scholars have found a variance in training and development programs across Indian organisations depending upon their nature, size, industry and corporate philosophy (Yadapadithaya, 2000). A study conducted by Upadhya (2006) found employees working in foreign subsidiaries of Indian IT firms travelling to their corporate HQ for training purposes. Similarly, Thite et al., (2012) also found the parent HQ of Indian IT MNEs to be in charge of training at the managerial-level. Additionally, when it comes to training at the technical and professional-level, Indian IT firms have been found to be relying on the use of internal promotions (Balaji, 2004) and job rotation to train employees in a variety of jobs within the organisation including lateral movements in vertically oriented careers to meet individual needs and the needs of the larger multinational organisation (Kuruvilla and Ranganathan, 2010).

\section{Pay \& Performance}

Traditionally, Indian organisations have offered lifetime employment and seniority-based pay to their employees (Venkata Ratnam, 1995). However, such practices not followed by all Indian organisations across all industries and particularly not in the Indian IT sector. A study conducted by Som (2007) found Indian firms and MNEs in IT to be relying on performance related pay and compensation practices. Furthermore, Budhwar et al., (2006) also found Indian business process 
outsourcing (BPO) firms to be relying on individual bonus schemes while implementing performance and skills based appraisal practices. In terms of benefits, Indian IT firms mostly provide rewards such as merit bonuses, cash awards and allowances for skills development of their employees (Ahlfors, 2011).

\section{Engagement \& Communication}

The Indian value system promotes employees to not speak against one's supervisor as it may disrupt supervisor-subordinate harmony (Saini and Budhwar, 2008). Employee involvement and participation within Indian IT firms has therefore remained at an all-time low (Rao et al., 1999) due to the high power distance and strong collectivist culture of India (Budhwar and Sparrow, 2002; Budhwar et al., 2006; Gopalan and Rivera, 1997) and this is also reflected in employee engagement and communication practices adopted in Indian organisations including its IT industry. A study conducted by Bhatnagar (2007) found employees working in Indian IT firms disengaged from their work due to a mismatch between their work expectations and their actual role and also due to the lack of clarity in communications within the organisation.

(Insert Table 1 about here)

\section{The Golden Triangle for MNEs}

The theoretical perspective of the "Golden Triangle" for MNEs was recently proposed by Pudelko and Harzing (2008) to characterise all the global integration versus local responsiveness 
choices faced by MNEs and to examine the extent to which their subsidiary HRM practices resemble those of local firms or their parent organisation. Based on a survey, Pudelko and Harzing (2008) came to the conclusion that the debate on standardisation versus location should be extended due to complexity in IHRM and they, therefore, proposed that standardisation can not only take place towards the HQ but also towards global "best" practices, wherever they originate from within the global MNE network (Ruel and Bondarouk, 2012). Accordingly, in today's global multinational environment, ethnocentric approaches to HR may no longer be sustainable as MNEs can adopt one of the following three approaches to the transfer of their HRM: 1) standardisation towards HQ, 2) localisation of HRM practices, and 3) standardisation towards global "best” practices (Pudelko and Harzing, 2008).

Standardisation of HQ practices typically refers to the alignment of subsidiary HR (and management) practices towards the HQ of the parent company in its home-country. For example, American MNEs prefer a centralised approach to HRM as compared to German or Japanese MNEs with HQ playing a significant role in disseminating similar practices across a range of issues in their subsidiaries; like collective bargaining, payment systems, training and so on (Ferner et al., 2006). American MNEs, therefore, standardised their HR policies and practices to a greater extent as compared to other MNEs. Localisation of HRM practices, on the other hand, highlights which HRM practices in the foreign subsidiary should be localised to the host-country standards. For instance, in some situations complying with local subsidiary conditions makes for greater operational efficiency (Lee and Yarwood, 1983). As a result, MNEs may be inclined towards adopting a localised approach to HRM in order to deal with the local pressures of educational standards, labour market conditions, legislation, trade union and so on (Wood, 
Brewster and Brookes, 2014). For instance, a study conducted by Edwards and Zhang (2003) found Chinese MNEs in the UK adopting a localisation HR strategy due to cultural and regulatory constraints and also as a deliberate response to learning "best" practices to speed up their internationalisation process.

Finally, standardisation towards global "best" practices means that MNEs may adopt universal best HR practices in their network of subsidiaries regardless of their national origin. More particularly, HRM in this approach is largely standardised and centralised incorporating global best practices, and global benchmarking including compliance with policies, processes and guidelines that have been standardised worldwide (Aswathappa and Dash, 2007). For example, "Korean MNEs have carefully selected components of HR practices for global standardisation based on relevant logics of action (e.g. sharing global corporate values, facilitating international transfer of employees etc.) to implement their global "best" HRM practices, which is also based on the model of US MNEs approach to global standardisation (Chung and Furusawa, 2016). In summary, the debate on standardisation and localisation using the golden triangle proposes that the successful management of subsidiaries in foreign countries with respect to the transfer of HRM is not only about a dual challenge but a triangular challenge for MNEs (Pudelko and Harzing, 2008).

Interestingly, despite being the most relevant, recent and practicable work and theory on standardisation versus localisation debate in MNEs, no study (that the authors are aware of) so far has utilised this framework to examine the transfer of HRM practices, particularly in an EMNE context. Given that the three categories proposed by Pudelko and Harzing (2008) 
encapsulate all the strategic choices in the "global versus local" debate; we adopt this framework for this study. Figure 1, provides a theoretical model that has been developed for this study using the golden triangle for MNEs framework.

(Insert Figure 1 about here)

\section{Methodology}

A qualitative method that uses semi-structured interviews to gather data on the transfer of HRM practices in EMNEs and particularly Indian IT MNEs was adopted for this study. This method was used for this study due to its exploratory focus and because it fits with the study's research questions and its theoretical framework. For instance, despite the prominent growth achieved by the Indian IT industry and its multinational enterprises, there is insufficient literature about the HRM practices in this industry (Mathew and Jain, 2008). In such circumstances, where theory is weak and the purpose of the research is exploratory, there is a strong case for the use of qualitative research design (Creswell, 2009). In addition, the majority of studies that have examined the transfer of HRM practices are based upon large-scale surveys that rely on questionnaires to test hypotheses (Gamble, 2003; Wright and Gardner, 2000). This has resulted in the development of a large set of generalised findings that are based on the use of pure statistical data (Patton, 2002). On the contrary, using qualitative methods would allow the researcher to provide a richer and fuller understanding of the human resource issues and challenges in the Indian IT industry (Agrawal and Thite, 2003, p.252) including its MNEs. It is therefore very suitable and a fitting method for this exploratory research agenda. 
Considering that aim of this study is to examine the transfer of HRM practices in Indian IT MNEs regardless of their size, a list 19 organisations was created and identified, out of which 15 organisations agreed to participate in this study. The organisations included two small firms (approximately 25 to 100 employees), six medium-sized firms (approximately 200 to 500 employees) and seven large firms (approximately 1000 to 3000 employees). These Indian IT organisations were identified from NASSCOM's (the National Association of Software and Services Companies) membership directory (i.e. the premier body that represents the Indian IT industry) and were selected through purposive sampling technique. The organisations are all located in major cities across Australia like, Sydney, Melbourne, Brisbane and Perth. The companies were contacted initially through telephone calls to obtain verbal consent, after which formal appointments for a face-to-face interview were set with the respective participants. The participants mainly included senior managers working in the Australian operations of Indian IT firms; they were the key decision makers at the subsidiary and were therefore selected as the primary respondent for the interviews. Accordingly, 18 interviews were conducted in total that mostly included a single participant in each organisation including two participants in a couple of organisations. This was mainly done to check for the consistency and the reliability in the data being gathered. The interviews lasted for approximately 60 to 80 minutes and broadly included questions on areas like, role of the participant, Australian subsidiary operations, transfer of HRM practices, and role of contextual factors.

Once, the interviews were conducted, they were manually transcripted and were proofread twice for any errors. The researchers then compared the data in the transcript with the themes in the interview guide to look for ideas emerging from the data and how they relate to the interview 
questions. This was then followed by an open coding process where words, phrases, and ideas appearing frequently in the interview transcripts were organised into codes (Charmaz, 2006). Subsequently, the researchers then used an axial coding process to identify the interrelationships among the open codes by grouping them into themes or categories (Corbin and Strauss, 2007). During this process, the researchers also searched for negative instances in the patterns emerging out of interview data (i.e. outliners) whilst comparing it with the pre-existing coded data to seek differences and their possible explanations (Miles and Huberman, 1994). To validate the data, the researchers employed an external peer review process where few passages from the preexisting open and axial coded data including the list of codes were provided to an external researcher for the creation of new coding categories which were then compared to the codes developed by the researchers. The identity of the participants throughout this process was protected. Finally, the entire data was analysed using interpretive thematic analysis (Braun and Clarke, 2006) to search for repeated patterns of meaning and analyse and report them. Table 2 presents a profile of the organisations and the participants that took part in this study and while Table 3 present an example of coding and statements from the respondents.

(Insert Table 2 about here)

(Inset Table 3 about here)

\section{Findings}

The results show some interesting findings on the transfer of HRM practices in Indian IT MNEs. From the 18 interviews across 15 subsidiaries conducted, the data showed that in almost all the 
15 organisations, the recruitment \& selection was managed from the HQ using global staffing practices. Training \& development was found to be HQ controlled; however, across seven organisations, local subsidiary-level training was also provided to the employees. Furthermore, across eight organisations, the HQs were found be in-charge of the payroll while in seven organisations the payroll was managed locally by the subsidiaries; performance management was conducted locally by the subsidiaries but was managed centrally by the HQs. Finally, employee engagement \& communication at the subsidiaries was found to be very limited due to the level of centralisation found across the subsidiaries. Table 4 provides the results of the transfer of HRM practices within each subsidiary of Indian IT MNEs along the four HR practices categories.

(Insert Table 4 about here)

\section{Recruitment \& Selection}

Indian IT MNEs mainly rely on the use of expatriate employees using global staffing to fill managerial and technical positions in their Australian subsidiaries. This was found across all the 15 subsidiaries. For instance, the majority of employees in the Australian subsidiaries of Indian IT firms come from their company's parent-country operations in India, and also occasionally from their MNE global network via internal transfers and "word of mouth". The reason for bringing senior managers from India was to staff them in key subsidiary positions to manage the Australian operations while technical (or professional) employees oversee the delivery and implementation of their company's IT projects using the "offshore-onsite" model. Relatively, the 
Indian IT firms emphasise on the use of job rotation and internal transfers to bring expatriate managerial and technical employees through short-term and long-term, temporary work visas (i.e. 457 work visa) for a period of two to four years. While the managerial staff mostly stays with the subsidiary over a longer period, the technical staff are either sent back to the head office in India or assigned to work in other subsidiary locations [in the US, UK or Europe] to manage other IT projects of the company. Accordingly, in all the organisations in this sample, it was

found that the Australian subsidiaries were overwhelmingly staffed by expatriates from the Indian operations. This was explained by two subsidiary senior managers:

We mainly rely on internal transfers, where employees come to Australia on international assignments for the duration of two to four years to manage specific IT projects, and then travel to other subsidiary locations within the network of our larger MNE; this is more a staffing practice rather than a recruitment policy (manager J)

Another manager said

We have specialised employees who come from India and hold expertise in specific areas of IT to deliver on specific projects. They are sent to our Australian operations due to the specific demands we get from our clients and customers and that is why we have a staffing policy where $H Q$ decides which employee should be sent on international assignment to our subsidiary (manager $H$ ).

\section{Training \& Development}


Indian IT MNEs provide training to their subsidiary employees in Australia through frequent HQ visits, online training and induction as well as through the use of local "in-house" trainers. For instance, when it comes to managerial training, the HQ in all 15 organisations was found to be in-charge as managers from the subsidiary frequently visited the Indian operations on a yearly and half yearly basis to get briefed and coached on their international assignments. As explained by one manager:

Strategically, our training is always driven from our head office and our "centre of excellence" in India and that is because are solutions are largely driven there (manager K)

With respect to the training of technical/professional employees, it was found that employees at the Australian subsidiary participated in local inductions and also completed online-based [intranet] training that was managed centrally from the HQs. The managers routinely described this as "self-service" training. As noted by the manager of subsidiary L:

We have an online system in place that provides self-service training to our employees in our subsidiary. The majority of our subsidiary training is conducted through web-based programs and online platforms and, occasionally by teaming up with our HR staff in India (manager L). 
However, in seven out of 15 subsidiaries, additional face-to-face [classroom] training was also provided to the employees. This was done by taking services from a local (i.e. Australian) thirdparty training provider, referred to as "in-house consultants". These providers offer credit points to employees from completing skills and domain-based [technical] training within a specific period of time.

With regards to employee development initiatives in Indian IT firms, a number of techniques such as, promotion, job rotation, succession planning, coaching and mentoring were used to manage the career development of employees, consistent with the global staffing practices used by these firms. For example, organisation c rewarded its employees with expatriation i.e. - the opportunity to work in different parts of the world and learn about the MNE. Similarly, organisation E ran career development programs like, "mentorship" and "home-grown leaders" via coaching and succession planning to identify internal talent. The manager of subsidiary $\mathrm{L}$ said:

We rely on a number of techniques to manage and develop the careers of our employees; for example, certification courses, succession planning, coaching and so on. The idea is that it is all linked with the aspirational roles and future careers of our employees regardless of where they are located within our MNE global network (manager L).

\section{Pay \& Performance}


Indian IT MNEs rely on a mix of parent-country and local practices for pay and compensation of their employees in their Australian subsidiaries. That is, across eight organisations, the payroll was managed by the head office while in seven subsidiaries, the payroll was managed locally. In addition, the payment of salaries and allowances for all employees was done according to local awards while the role of the subsidiaries was to provide information to HQs around Australian market pay rates and awards. This was explained by a subsidiary manager:

The processing of payroll for our subsidiary staff happens in India; however, we take services from Australian payroll and taxation consultants to provide market intelligence regarding payment of salaries and benefits (manager $N$ ).

Other HRM practices, such as performance management were also managed from the Indian operations of Indian IT firms and were found to be standardised and global across all the subsidiaries. They were associated with the achievement of specific and measurable goals indicative of a merit-based system that relies on timesheets and scorecards. The performance appraisal results once generated were sent back to HQs for evaluation and benchmarking indicating organisation wide presence of pay for performance system in place. As explained by managers of subsidiary $\mathrm{B}$ and $\mathrm{H}$

The performance reviews criteria and frameworks used in our subsidiary are global and managed by our HR team in India. The appraisals usually are conducted locally in our subsidiary where we focus on KPIs such as business results, client feedback, targets, 
values, creativity and so on. They are mainly numeric in nature, however, we do focus on qualitative measures also (manager B).

And

Payment of salaries is directly related to the performance levels attained by each and every employee based in Australia (manager $H$ ).

\section{Engagement \& Communication}

Indian IT MNEs do not implement any formal mechanisms to engage or communicate with employees based in their Australian subsidiaries. For instance, in almost 14 organisations, it was found that employees had very limited participation in decision-making with respect to subsidiary operations due to centralisation found across the subsidiaries. However, we did notice subsidiary managers interacting with subordinates and staff informally to motivate them. In addition, employees were also not briefed on the business strategy or finance performance of their Australian operations (or the larger organisation). Communication, therefore, took a downward route as much of information was supplied through newsletters, memos and emails. For instance, the majority of the information that was provided to the subsidiary staff was made available through the Indian IT firm's respective intranet portal. This sentiment was reflected in the following quotes: 
The involvement is definitely there in the areas of marketing and delivery of our IT services but not on issues that involve decision making, as usually managers have the authority to make decisions, keeping the Indian head office in loop (manager D).

Another manager said:

Communicating to all employees is not on the most top of our agenda as our managers are typically informed of any major decisions taken by the company. Also, these days, technology has enabled our staff to communicate with our counterpart in India so we don't have to go out of our way to do things differently (manager A).

Table 5 provides a summary of the findings of HR practices that were found in the subsidiaries of Indian IT firms in Australia.

(Insert Table 5 about here)

\section{Discussion and Implications}

The findings from this study indicate that the Australian subsidiaries of Indian IT MNEs mainly adopt their home country HR practices with some level of localisation to suit the Australian subsidiary context. Relatively, a presence of both, "pull" and "push" HR forces was found in these subsidiaries. For instance, the pull force with respect to HR was found in the area of training, career development and performance appraisal methods while the push force was more 
evident in their recruitment and workforce allocation, salaries and payroll and engagement and communication areas. Accordingly, Indian IT MNEs adopted a "hybrid" approach to the transfer of HRM practices, combing mainly their home-country practices with local Australian practices. For example, Indian IT firms, whilst providing HQ-based training also spent a percentage of their subsidiary revenue to provide local training to their Australian subsidiary staff to meet legal as well as customer requirements. In addition, Indian IT MNEs also processed the salaries of their subsidiary staff from their home-country but paid them according to local Australian awards. Clearly, Indian IT MNEs are combining their HQ practices with local (Australian) practices to adopt a mix of "ethnocentric" and "polycentric" approaches (Perlmutter, 1969) to the transfer of HRM in their subsidiaries in Australia. Given the kind of work the subsidiaries were engaged in (i.e. providing IT services and offshoring majority of work to centres of excellence in India), it seemed fair that the HQs in India saw a specific need to keep many of the HR practices intact while "fine-tuning" some of them to suit their Australian subsidiary context. This explains why Indian IT MNEs prefer to adopt a modification style of HRM in their overseas subsidiaries in developed countries. The findings in this study, therefore, do not fully correspond with the argument that EMNEs adopt a more "polycentric" approach to the transfer of HR practices in developed countries (Thite et al., 2012; Thite, 2012; 2015). They further support extant research that has found EMNEs adopting a blend of home and host-country HR practices (Ying Chang et al., 2007; Chung et al., 2014).

The findings also do not agree with the idea that EMNEs mostly prefer to hire host-country managers, maintain high external consistency and transfer host-country knowledge gained back to the HQ, using a "two-way" approach to HRM (Thite et al., 2012; Zhang, 2003) as results 
indicated the use of global staffing practices to bring skilled expatriates (i.e. knowledge workers) from home-country to maintain internal consistency while also being locally responsive to the extent that local needs were met, thus engaging in "forward diffusion" of HRM coupled with modification. The importance of transferring centralised expertise through the "onsite-offshore" model and via expatriates through global staffing in Indian IT firms, therefore, cannot be overlooked as HQ maintained control over majority of the HR decisions in the Australian subsidiaries. This minimised the liability of country of origin and the liability of foreignness in these firms (Horwitz and Budhwar, 2015) due to the overwhelming presence of expatriates from the home country and other subsidiary locations within the MNE global network. What we have found is that EMNEs do not behave significantly different to Western MNEs that transplant their ideas and practices to their subsidiaries in foreign countries but also engage in some level of localisation (Gamble, 2010; Yahiaoui, 2015). However, most importantly, the difference lies in the fact that Indian IT firms give majority of importance to their home-country practices but localise some of those practices to fit into Australian standards in order to maintain a certain degree of local flexibility in their Australian subsidiaries, and to meet the local demands and deal with any challenges faced. We, therefore, find that the major source of origin for these "hybrid" HR practices is the parent-country operations (or HQ in other words) of Indian IT firms rather than the so-called "global best practices" as claimed by (Chung et al., 2014). This is a novel finding that shows that "hybrid" HR practices in MNEs do not necessarily originate from global "best" practices but can also emerge from the home-country of an MNE.

When looked upon through the theoretical lens of the "golden triangle" for MNEs (Pudelko and Harzing, 2008), it becomes apparent that the choice regarding the transfer of HR practices in 
MNEs in not just about a triangular challenge as it adds further complexity to the existing choices in the global integration versus local adaptation of HRM. We, therefore, propose a new category to be added to this model -"Hybridisation towards HQ-subsidiary practices" to make it more complete due to the aforementioned reasons and to represent all the integration-localisation options faced by MNEs. Our study, therefore, is the first to propose an extension to this model. We call this extended model, "The MNE Diamond” (see Figure 2).

(Insert Figure 2 about here)

The practical implication is that while the deliberate approach to modifying the HR practices to a mix of home and host-country style is suitable for Indian IT MNEs, their business model and the manner in which they deliver their IT services using skilled expertise from their home-country operations in Australia, they will need to consider investing into HRM more heavily including providing more autonomy to subsidiaries with respect to HR decision making if they want to grow and compete with global MNEs in developed markets. In terms of the future studies, while the sample in this study was exclusively limited to examining the HR practices in Indian IT firms and their MNEs, more studies should be conducted on examining HRM strategies and practices in other firms from other emerging economies (like China or South Korea) and how they operate in developed countries including focusing on other sectors (like manufacturing or other kinds of services - as the findings, in this case, may be very specific to the firms operating in the IT sector). Finally, the study has its limitations that include a focus on a single unit and single industry analysis (i.e. subsidiary and IT), and interviews single respondents in most cases; we 
recommend that future studies should focus on interviewing multiple respondents and employing more rigorous methods like, case studies or mixed-methods.

\section{Conclusion}

After carefully analysing the data and discussing the implications it has on this study, it is apparent that Indian IT MNEs mainly transfer their home-country HR practices whilst maintaining some degree of localisation in their subsidiaries in Australia. Due to the global staffing practices adopted by Indian IT MNEs that draws on centralised expertise using skilled expatriates, the role of the HQs in centrally managing the HR activities of subsidiaries albeit with some localisation cannot be emphasised enough as it allowed Indian IT firms to maintain a delicate balance between HQ-oriented and local (subsidiary) practices. There is little doubt that as more and more EMNEs operate in developed countries, they will more likely adopt a "hybrid" approach to HRM as opposed to just ethnocentric or polycentric approach to operating in developed countries. However, more studies are required to further our understanding of the transfer of HRM practices in developed country subsidiaries of EMNEs. 


\section{References}

Agrawal, N.M., and Thite, M. 2003. Human resource issues, challenges and strategies in the Indian software industry. International Journal of Human Resources Development and Management, 3(3): 249-264.

Ahlfors, M. 2011. Engaging Indian IT Employees A Compensation \& Benefits Case Study of a Finnish Multinational IT Company. Final thesis for master of economics, Aalto University. From http://hsepubl. lib. hse.fi/FI/ethesis/pdf/12601/hse_ethesis_12601.pdf.

Almond, P. 2011. Re-visiting "country of origin" effects on HRM in multinational corporations. Human Resource Management Journal, 21(3): 258-271.

Aswathappa, K., and Dash, S. 2007. International human resource management. New Delhi: Tata McGraw-Hill

Bhatnagar, J. 2007. Talent management strategy of employee engagement in Indian ITES employees: key to retention. Employee relations, 29(6): 640-663.

Balaji, E. 2004. "Preserving the boom". Praxis-Business Line's Journal on Management, January, 36-41.

Braun, V., and Clarke, V. 2006. Using thematic analysis in psychology. Qualitative research in psychology, 3(2): 77-101.

Budhwar, P. S. 2008. Challenges facing Indian HRM and the way forward. In P. S. Budhwar., and J. Bhatnagar (Eds.). The changing face of people management in India: 287, London: Routledge.

Budhwar, P.S., and Bhatnagar, J. (Eds.) 2008. The changing face of people management in India. Routledge. 
Budhwar, P.S., Luthar, H.K., and Bhatnagar, J. 2006. The dynamics of HRM systems in Indian BPO firms. Journal of Labor Research, 27(3): 339-360.

Budhwar, P.S., and Khatri, N. 2001. A comparative study of HR practices in Britain and India. International Journal of Human Resource Management, 12(5): 800-826.

Budhwar, P.S., and Sparrow, P.R. 2002. Strategic HRM through the cultural looking glass: mapping the cognition of British and Indian managers. Organization Studies, 23(4): 599-638.

Budhwar, P., and Varma, A. 2010. Guest editors' introduction: emerging patterns of HRM in the new Indian economic environment. Human Resource Management, 49(3): 345-351.

Budhwar, P.S., and Varma, A. 2011. Emerging HR management trends in India and the way forward. Organizational Dynamics, 40(4): 317-325.

Budhwar, P.S., Varma, A., Malhotra, N., and Mukherjee, A. 2009. Insights into the Indian call centre industry: can internal marketing help tackle high employee turnover?. Journal of Services Marketing, 23(5): 351-362.

Calhoun, M.A. 2002. Unpacking liability of foreignness: identifying culturally driven external and internal sources of liability for the foreign subsidiary. Journal of International Management, 8(3): 301-321.

Cappelli, P., Singh, H., Singh, J., and Useem, M. 2010. The India way: Lessons for the US. The Academy of Management Perspectives, 24(2): 6-24.

Chang, Y.Y., Mellahi, K., and Wilkinson, A. 2009. Control of subsidiaries of MNCs from emerging economies in developed countries: the case of Taiwanese MNCs in the UK. The International Journal of Human Resource Management, 20(1): 75-95.

Chatterjee, S. R. 2007. Human resource Management in India: "Where from" and "where to"? Research and Practice in Human Resource Management, 15(2): 92-103. 
Charmaz, K. 2006. Constructing grounded theory: A practical guide through qualitative research. London: Sage Publications.

Chen, S.J., Lawler, J.J., and Bae, J. 2005. Convergence in human resource systems: A comparison of locally owned and MNC subsidiaries in Taiwan. Human Resource Management, 44(3): 237-256.

Corbin, J., and Strauss, A. 2007. Basics of qualitative research. $3^{\text {rd }}$ edition, Thousand Oaks, CA: Sage.

Chung, C. and Furusawa, M., 2016. The HRM of Foreign MNCs Operating in Europe. International Human Resource Management: Contemporary HR Issues in Europe: 169.

Chung, C., Sparrow, P., and Bozkurt, O. 2014. South Korean MNEs' international HRM approach: Hybridization of global standards and local practices. Journal of World Business, 49(4): 549-559.

Creswell, J. W. 2009. Research design: Qualitative, quantitative and mixed method approaches. $3^{\text {rd }}$ edition, Thousand Oaks, CA: Sage.

Edwards, T., and Ferner, A. 2004. Multinationals, reverse diffusion and national business systems. In Management International Review, 49-79. Gabler Verlag.

Edwards, T., Lavelle, J., Minbaeva, D., Sanchez-Mangas, R., and Jalette, P. 2014. Global standardization or national differentiation of HRM practices in multinational companies?. In Proceedings of the 56th Annual Meeting of the Academy of International Business. Academy of International Business.

Edwards, C., and Zhang, M. 2003. Human resource management strategy in Chinese MNCs in the UK: A case study with six companies. Research and Practice in Human Resource Management, 11(1): 1-14. 
Fan, D., Zhang, M.M., and Zhu, C.J. 2013. International human resource management strategies of Chinese multinationals operating abroad. Asia Pacific Business Review, 19(4): 526-541.

Ferner, A. 2009. HRM in multinational companies. In A. Wilkinson, N Bacon, T. Redman, and S Snell (Eds.), The sage handbook of human resource management: 539-558, Thousand Oaks, CA: Sage.

Ferner, A., Gunnigle, P., Quintanilla, J., Wachter, H., and Edwards, T. 2006. Centralization In P. Almond., and A. Ferner (Eds.). American multinationals in Europe: Managing employment relations across national borders: 197-222, New York: Oxford University Press.

Festing, M., Knappert, L., Dowling, P.J., and Engle, A.D. 2012. Global Performance Management in MNEs - Conceptualization and Profiles of Country-Specific Characteristics in China, Germany, and the United States. Thunderbird International Business Review, 54(6): 825843.

Gamble, J. 2003. Transferring human resource practices from the United Kingdom to China: the limits and potential for convergence. International Journal of Human Resource Management, 14(3): 369-387.

Gamble, J. 2010. Transferring organizational practices and the dynamics of hybridization: Japanese retail multinationals in China. Journal of Management Studies, 47(4): 705-732.

Gaur, A.S., Kumar, V., and Sarathy, R. 2011. Liability of foreignness and internationalization of emerging market firms. Advances in International Management, 24: 211-233.

Ghosh, P. 2007. Recruitment Strategies Exploring the Dimensions in the Indian Software Industry. Asian Journal of Management Cases, 4(1): 5-25. 
Glover, L., and Wilkinson, A. 2007. Worlds colliding: the translation of modern management practices within a UK based subsidiary of a Korean-owned MNC. The international journal of human resource management, 18(8): 1437-1455.

Gomes, E., Sahadev, S., Glaister, A.J., and Demirbag, M. 2015. A comparison of international HRM practices by Indian and European MNEs: evidence from Africa. The International Journal of Human Resource Management, 26(21): 2676-2700.

Gopalan, S., and Rivera, J.B. 1997. Gaining a perspective on Indian value orientations: Implications for expatriate managers. The International Journal of Organizational Analysis, 5(2):156-179.

Horwitz, F., and Budhwar, P. (Eds.). 2015. Handbook of human resource management in emerging markets. Edward Elgar Publishing.

Khandekar, A., and Sharma, A. 2006. Organizational learning and performance: Understanding Indian scenario in present global context. Education + Training, 48(8/9): 682-692.

Khavul, S., Benson, G.S., and Datta, D.K. 2010. Is internationalization associated with investments in HRM? A study of entrepreneurial firms in emerging markets. Human Resource Management, 49(4): 693-713.

Kumar, N. 2013. India's global powerhouses: How they are taking on the world. Harvard Business Press.

Kuruvilla, S., and Ranganathan, A., 2010. Globalisation and outsourcing: confronting new human resource challenges in India's business process outsourcing industry. Industrial Relations Journal, 41(2): 136-153.

Lee, Y., and Larwood, L. 1983. The socialization of expatriate managers in multinational firms. Academy of Management Journal, 26(4): 657-665. 
Lovett, S.R., Pérez-Nordtvedt, L., and Rasheed, A.A. 2009. Parental control: A study of US subsidiaries in Mexico. International Business Review, 18(5): 481-493.

Mathew, M., and Jain, H.C. 2008. International human resource management in the Indian information technology sector: A comparison of Indian MNCs and affiliates of foreign MNCs in India. Advances in International Management, 21: 267-297.

McDonnell, A., Stanton, P., and Burgess, J. 2011. Multinational enterprises in Australia: Two decades of international human resource management research reviewed. Asia Pacific Journal of Human Resources, 49(1): 9-35.

Miles, M.B., and Huberman, A.M. 1994. Qualitative data analysis: An expanded sourcebook. Sage.

Nilekani, N. 2009. Imagining India: The idea of a renewed nation. Penguin.

Oyelere, M. 2014. Insights into the principles and strategies of human resource management practices in multinationals enterprises based in Nigeria. Working Paper 1405: RWPBM1405, Regent's University, London.

Patton, M.Q. 2002. Qualitative interviewing. Qualitative research and evaluation methods, 3, 344-347.

Perlmutter, H.V. 1969. The tortuous evolution of the multinational corporation. Columbia Journal of world business, 4(1): 9-18.

Pio, E. 2007. HRM and Indian epistemologies: A review and avenues for future research. Human resource management review, 17(3): 319-335.

Pudelko, M., and Harzing, A.W. 2008. The Golden Triangle for MNCs: Standardization towards headquarters practices, standardization towards global best practices and localization. Organizational dynamics, 37(4): 394-404. 
Rao, S.S., Raghunathan, T.S., and Solis, L.E., 1999. The best commonly followed practices in the human resource dimension of quality management in new industrializing countries: The case of China, India and Mexico. International Journal of Quality \& Reliability Management, 16(3): $215-226$.

Ruël, H.J., and Bondarouk, T. 2012. A cross-national perspective on the intersection between information technology and HRM. Handbook of Research on Comparative Human Resource Management: 416

Saini, D.S., and Budhwar, P.S. 2008. Managing the human resource in Indian SMEs: The role of indigenous realities. Journal of World Business, 43(4): 417-434.

Saini, D.S., and Budhwar, P.S. 2013. Human Resource Management in India. Managing human resources in Asia-Pacific, 20: 126.

Sethi, D. 2005. A study of recruitment and selection practices of IT-ITES firms in India, Master's Dissertation, University of Nottingham, UK.

Som, A., 2007. What drives adoption of innovative SHRM practices in Indian organizations?. The International Journal of Human Resource Management, 18(5): 808-828.

Sparrow, P., and Budhwar, P. 1997. Competition and change: Mapping the Indian HRM recipe against world-wide patterns. Journal of World Business, 32(3): 224-242.

Thite, M. 2012. Strategic global human resource management: Case study of an emerging Indian multinational. Human Resource Development International, 15(2): 239-247.

Thite, M. 2015. International HRM in emerging economies In F. Horwitz, and P. Budhwar (Eds.). Handbook of human resource management in emerging markets: 97-121, Edward Elgar Publishing. 
Thite, M., Budhwar, P., and Wilkinson, A. 2014. Global HR roles and factors influencing their development: Evidence from emerging Indian IT services multinationals. Human Resource Management, 53(6): 921-946.

Thite, M., Wilkinson, A., and Shah, D. 2012. Internationalization and HRM strategies across subsidiaries in multinational corporations from emerging economies-A conceptual framework. Journal of World Business, 47(2): 251-258.

Upadhya, C., 2006. The Global Indian Software Labour Force: IT Professionals in Europe. Indo-Dutch Programme on Alternatives in Development, Working paper series, (1).

Venkata Ratnam, C.S. 1995. Economic liberalization and the transformation of industrial relations policies in India. Employment relations in the growing Asian economies: 248-314.

Yahiaoui, D. 2015. Hybridization: Striking a balance between adoption and adaptation of human resource management practices in French multinational corporations and their Tunisian subsidiaries. International Journal of Human Resource Management, 26(13): 1665-1693.

Yildiz, H.E., and Fey, C.F. 2012. The liability of foreignness reconsidered: New insights from the alternative research context of transforming economies. International Business Review, 21(2): 269-280.

Kim, K., Park, J.H., and Prescott, J.E. 2003. The global integration of business functions: A study of multinational businesses in integrated global industries. Journal of International Business Studies, 34(4): 327-344.

Pudelko, M., and Harzing, A.W. 2007. Country-of-origin, localization, or dominance effect? An empirical investigation of HRM practices in foreign subsidiaries. Human Resource Management, 46(4): 535-559. 
Wilkinson, A., Wood, G., and Demirbag, M. 2014. Guest editors' introduction: People management and emerging market multinationals. Human Resource Management, 53(6): 835849.

Wood, G., Brewster, C., and Brookes, M. 2014. Human resource management and the institutional perspective. Routledge. Working Series Paper, Center for Advanced Human Resource Studies, Cornell University, USA.

Wright, P.M., and Gardner, T.M. 2000. Theoretical and empirical challenges in studying: the HR practice-firm performance relationship.

Yadapadithaya, P.S. 2000. International briefing 5: Training and development in India. International Journal of Training and Development, 4(1): 79-89.

Ying Chang, Y., Wilkinson, A.J., and Mellahi, K. 2007. HRM strategies and MNCs from emerging economies in the UK. European Business Review, 19(5): 404-419.

Zhang, M. 2003. Transferring human resource management across national boundaries: The case of Chinese multinational companies in the UK. Employee Relations, 25(6): 613-626.

Zhang, A.Y., Tsui, A.S., Song, L.J., Li, C., and Jia, L. 2008. How do I trust thee? The employeeorganization relationship, supervisory support, and middle manager trust in the organization. Human Resource Management, 47(1): 111-132.

Zhu, C.J., Thomson, S.B., and De Cieri, H. 2008. A retrospective and prospective analysis of HRM research in Chinese firms: Implications and directions for future study. Human Resource Management, 47(1): 133-156. 


\section{Appendix}

Table 1: HRM Practices Used by Indian IT MNEs

\begin{tabular}{|c|c|}
\hline Recruitment \& Selection & $\begin{array}{l}\text { - Transfer of professional and managerial staff } \\
\text { - Internal transfers and Job rotation } \\
\text { - Online recruitment, referrals and advertisements }\end{array}$ \\
\hline Training \& Development & $\begin{array}{l}\text { - Employee travelling to } H Q \\
\text { - Promotion and job rotation as training } \\
\text { - Use of vertical careers. }\end{array}$ \\
\hline Pay \& Performance & $\begin{array}{l}\text { - Skills-based appraisal } \\
\text { - Pay for performance } \\
\text { - Merit bonuses and cash allowances }\end{array}$ \\
\hline Engagement \& Communication & $\begin{array}{l}\text { - Lack of formal engagement } \\
\text { - Mismatch between work expectations and the } \\
\text { - Lole assigned } \\
\text { - Lack of communication }\end{array}$ \\
\hline
\end{tabular}

(Source: Balaji, 2004; Bhatnagar, 2007; Budhwar et al., 2006; Ghosh and Geetika, 2007; Kuruvilla and Ranganathan, 2010; Mathew and Jain, 2008; Rao et al., 1999; Sethi, 2005; Som, 2007; Thite et al., 2012; Upadhya, 2007) 
Figure 1: Theoretical Model on the Transfer of HRM Practices in EMNEs using The Golden Triangle for MNEs
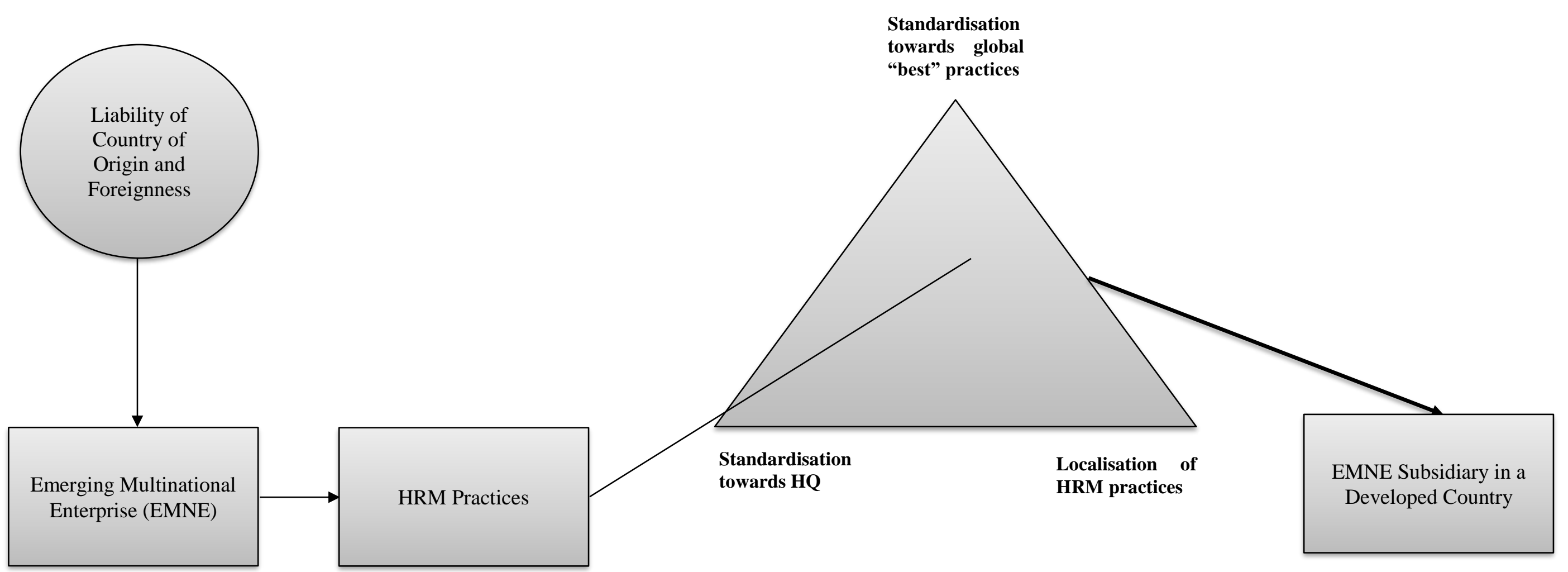
Table 2: Profile of Indian IT Organisations and their Respondents

\begin{tabular}{|c|c|c|c|c|c|}
\hline $\begin{array}{c}\text { Indian IT MNE } \\
\text { Participants }\end{array}$ & Industry & $\begin{array}{c}\text { Subsidiary } \\
\text { Location }\end{array}$ & $\begin{array}{c}\text { Subsidiary Size (Number of } \\
\text { Employees) }\end{array}$ & Respondents & Nationality \\
\hline Organisation $\mathrm{A}$ & IT Services & Brisbane & 50 & $\begin{array}{l}\text { Business } \\
\text { Relationship } \\
\text { Manager }\end{array}$ & Indian \\
\hline Organisation B & $\mathrm{BPO}$ & Sydney & 50 & Country Manager & Indian \\
\hline Organisation $\mathrm{C}$ & $\mathrm{BPO}$ & Sydney & 67 & Regional Manager & Indian \\
\hline Organisation D & $\begin{array}{l}\text { IT Services \& } \\
\text { Solutions }\end{array}$ & Sydney & 2900 & Country Manager & Australian \\
\hline Organisation E & $\begin{array}{l}\text { IT Services \& } \\
\text { Consulting }\end{array}$ & Melbourne & 500 & Country Manager & Indian \\
\hline Organisation $\mathrm{F}$ & $\begin{array}{l}\text { IT Services \& } \\
\text { Solutions }\end{array}$ & Sydney & 40 & Country Manager & Indian \\
\hline Organisation $\mathrm{G}$ & $\mathrm{BPO}$ & Sydney & 300 & $\begin{array}{l}\text { Country Manager } \\
\text { and HR Manager }\end{array}$ & Indian \\
\hline Organisation $\mathrm{H}$ & $\mathrm{BPO}$ & Sydney & 45 & HR Manager & Indian \\
\hline Organisation I & $\begin{array}{l}\text { IT Services \& } \\
\text { Solutions }\end{array}$ & Sydney & 25 & Country Manager & Indian \\
\hline Organisation $\mathrm{J}$ & IT Services & Sydney & 80 & $\begin{array}{l}\text { Operation Manager } \\
\text { and Sales Manager }\end{array}$ & $\begin{array}{l}\text { Indian and } \\
\text { Australian }\end{array}$ \\
\hline Organisation $\mathrm{K}$ & $\begin{array}{l}\text { IT Services \& } \\
\text { Consulting }\end{array}$ & Sydney & 100 & Operations Manager & Indian \\
\hline Organisation $\mathrm{L}$ & $\begin{array}{l}\text { IT Services \& } \\
\text { Consulting }\end{array}$ & Sydney & 1700 & HR Manager & British \\
\hline Organisation $\mathrm{M}$ & $\begin{array}{l}\text { IT Software and } \\
\text { Services }\end{array}$ & Sydney & 25 & $\begin{array}{l}\text { Business } \\
\text { Development } \\
\text { Manager }\end{array}$ & Australian \\
\hline Organisation $\mathrm{N}$ & IT Services & Melbourne & 1500 & Regional Manager & Indian \\
\hline Organisation $\mathrm{O}$ & $\begin{array}{l}\text { IT Services \& } \\
\text { Solutions }\end{array}$ & Melbourne & 50 & Regional Manager & Indian \\
\hline
\end{tabular}


Table 3: Example of Open and Axial Coding

\begin{tabular}{|c|c|c|}
\hline Open Codes & Axial Codes & Respondent Statements \\
\hline Global staffing & $\begin{array}{l}\text { Recruitment and } \\
\text { selection }\end{array}$ & $\begin{array}{l}\text { We make recommendations to our head office } \\
\text { based on the expertise needed to service our } \\
\text { local clients in Australia. The head-office then } \\
\text { makes a decision and sends staff to work in our } \\
\text { Australian subsidiary. Majority of our } \\
\text { employees come from India and also from our } \\
\text { subsidiaries in US, UK and Europe, however } \\
\text { they are also of Indian origin (manager c) }\end{array}$ \\
\hline $\begin{array}{l}\text { Travelling to HQ for } \\
\text { training }\end{array}$ & $\begin{array}{l}\text { Training and } \\
\text { development }\end{array}$ & $\begin{array}{l}\text { Training is largely driven from India as our } \\
\text { managers frequently travel to our head-office to } \\
\text { keep up to date with the projects we undertake } \\
\text { in our Australian operations; however, we also } \\
\text { provide some local training to our technical } \\
\text { staff here which is actually customised } \\
\text { according to the local needs and demands of } \\
\text { our clients (manager c) }\end{array}$ \\
\hline $\begin{array}{l}\text { Merit-based } \\
\text { performance }\end{array}$ & Pay and performance & $\begin{array}{l}\text { Our salaries and benefits are directly } \\
\text { proportional to the levels of performance we } \\
\text { expect from our employees. It is a measure } \\
\text { across both, an employee's performance and } \\
\text { their peer performance (manager } c \text { ). }\end{array}$ \\
\hline $\begin{array}{l}\text { Communicating } \\
\text { through newsletters, } \\
\text { emails and memos }\end{array}$ & $\begin{array}{l}\text { Engagement and } \\
\text { communication }\end{array}$ & $\begin{array}{l}\text { We mostly pass information to our employees } \\
\text { here through newsletters, emails and memos. } \\
\text { Sometimes we do conduct a meeting but that is } \\
\text { only when we have some major information to } \\
\text { share or issue to discuss otherwise we can just } \\
\text { telephone each other or send emails (manager } \\
\text { c) }\end{array}$ \\
\hline
\end{tabular}


Table 4: Results of the Transfer of HRM Practices in Indian IT MNEs

\begin{tabular}{|c|c|c|c|c|}
\hline \multirow{2}{*}{$\begin{array}{l}\text { Indian IT } \\
\text { MNEs }\end{array}$} & \multicolumn{4}{|c|}{ HRM Practices in Australian Subsidiaries } \\
\hline & $\begin{array}{l}\text { Recruitment \& } \\
\text { Selection }\end{array}$ & $\begin{array}{c}\text { Training \& } \\
\text { Development }\end{array}$ & $\begin{array}{c}\text { Pay \& } \\
\text { Performance }\end{array}$ & $\begin{array}{c}\text { Engagement \& } \\
\text { Communication }\end{array}$ \\
\hline Organisation A & $H Q$ & $H Q$ & $S$ & $H Q$ \\
\hline Organisation B & $H Q$ & $S$ & $H Q$ & $H Q$ \\
\hline Organisation $\mathrm{C}$ & $H Q$ & $H Q$ & $S$ & $H Q$ \\
\hline Organisation D & $H Q$ & $S$ & $S$ & $H Q$ \\
\hline Organisation $\mathrm{E}$ & $H Q$ & $H Q$ & $S$ & $H Q$ \\
\hline Organisation F & $H Q$ & $S$ & $S$ & $H Q$ \\
\hline Organisation $\mathrm{G}$ & $H Q$ & $S$ & $H Q$ & $H Q$ \\
\hline Organisation $\mathrm{H}$ & $H Q$ & $H Q$ & $H Q$ & $H Q$ \\
\hline Organisation I & $H Q$ & $S$ & $S$ & $H Q \& S$ \\
\hline Organisation $\mathrm{J}$ & $H Q$ & $H Q$ & $H Q$ & $H Q$ \\
\hline Organisation $\mathrm{K}$ & $H Q$ & $H Q$ & $S$ & $H Q$ \\
\hline Organisation L & $H Q$ & $S$ & $H Q$ & $H Q$ \\
\hline Organisation $\mathrm{M}$ & $H Q$ & $H Q$ & $H Q$ & $H Q$ \\
\hline Organisation $\mathrm{N}$ & $H Q$ & $H Q$ & $H Q$ & $H Q$ \\
\hline Organisation $\mathrm{O}$ & $H Q$ & $S$ & $H Q$ & $H Q$ \\
\hline
\end{tabular}


Table 5: HRM Practices Found in the Australian Subsidiaries of Indian IT MNEs

\begin{tabular}{|c|c|}
\hline Recruitment \& Selection & $\begin{array}{l}\text { - Recruitment through global staffing } \\
\text { - Transfer of expatriates from HQ and other subsidiaries } \\
\text { - } \quad \text { Internal transfers and Job rotation }\end{array}$ \\
\hline Training \& Development & $\begin{array}{l}\text { - Frequent } H Q \text { visits by managers } \\
\text { - Induction and online training by } H Q \\
\text { - Use of "in-house" trainers at the subsidiary }\end{array}$ \\
\hline Pay \& Performance & $\begin{array}{l}\text { - Payroll managed by } H Q \text { and subsidiary } \\
\text { - Skills and merit-based appraisal } \\
\text { - Pay for performance }\end{array}$ \\
\hline Engagement \& Communication & $\begin{array}{l}\text { - Limited involvement of employees } \\
\text { - Limited communication to subsidiary staff } \\
\text { - Use of newsletters, emails and memos }\end{array}$ \\
\hline
\end{tabular}


Figure 2: The MNE Diamond Model

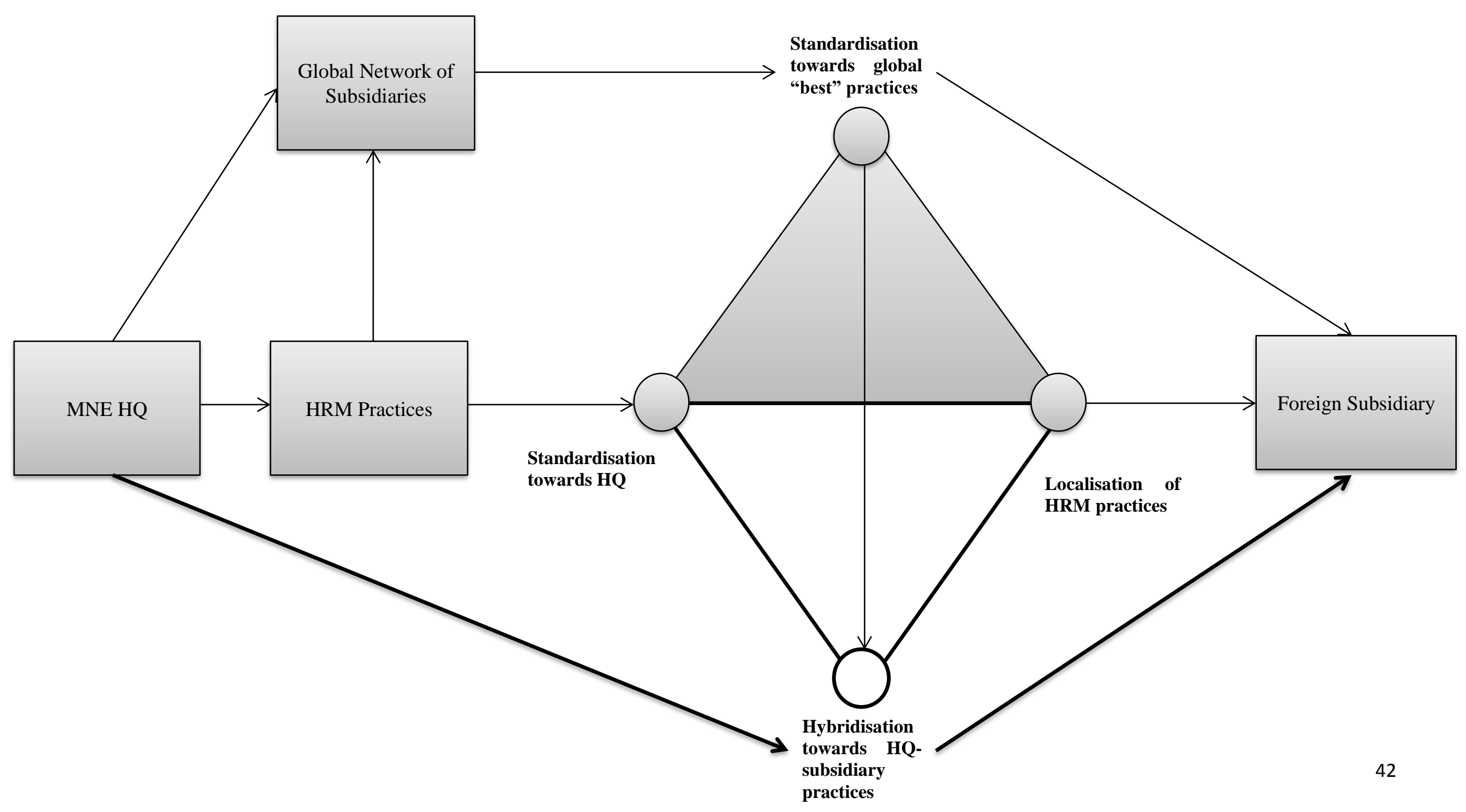

